\title{
Use of Preference Analysis to Identify Early Adopter Mind-Sets of Insect-Based Food Products
}

\author{
Isaac Ho ${ }^{1}\left(\mathbb{D}\right.$, Attila Gere $^{2}\left(\mathbb{D}\right.$, Charles $\mathrm{Chy}^{3}$ and Amy Lammert ${ }^{1, *(1)}$ \\ 1 CA-FSN Department, California Polytechnic State University, San Luis Obispo, CA 93407, USA; \\ iho01@calpoly.edu \\ 2 Institute of Food Science and Technology, Hungarian University of Agriculture and Life Sciences, \\ H-1118 Budapest, Hungary; gere.attila@uni-mate.hu \\ 3 MindCart AI, Allentown, PA 18103, USA; charles@mindcart.ai \\ * Correspondence: alammert@calpoly.edu
}

check for updates

Citation: Ho, I.; Gere, A.; Chy, C. Lammert, A. Use of Preference Analysis to Identify Early Adopter Mind-Sets of Insect-Based Food Products. Sustainability 2022, 14, 1435 https://doi.org/10.3390/su14031435

Academic Editor: Alessandra Durazzo

Received: 30 November 2021

Accepted: 21 January 2022

Published: 26 January 2022

Publisher's Note: MDPI stays neutral with regard to jurisdictional claims in published maps and institutional affiliations.

Copyright: (C) 2022 by the authors. Licensee MDPI, Basel, Switzerland. This article is an open access article distributed under the terms and conditions of the Creative Commons Attribution (CC BY) license (https:// creativecommons.org/licenses/by/ $4.0 /)$.

\begin{abstract}
Insects may potentially provide an alternative protein source. However, consumers may not easily accept insects due to feelings of disgust. Therefore, identifying early adopters of insect-based food products may determine their future acceptance. This study was conducted to (1) identify early adopter Mind-Sets of insect-based food products, (2) determine product features early adopters would prefer in an insect-based food product, and (3) determine differences in Mind-Sets in different countries. Two studies were distributed online in the US and the Philippines. The first study included information about insects, while the second study had no information on insects. The experimental design included elements, or product features, regarding insect-based products that participants evaluated. Preference Analysis was used to segment the participants into Mind-Sets. Based on the results, participants neither liked nor disliked the elements used. Participants in the studies without insect information were found to have higher liking when comparing liking. Participants who were aware of the study being about insects may have had less interest when evaluating the elements, as the response times between the US studies were significantly different $(p<0.05)$. The role of information and segmentation of the participants demonstrates the importance of experimental design when using Preference Analysis.
\end{abstract}

Keywords: preference analysis; mind-sets; early adopters; insects; insect-based food products

\section{Introduction}

By 2050, it is predicted that the human population will reach nine billion [1]. As a result, the United Nations has determined that food production will need to double to meet the needs of the growing population [2]. As developing countries require more meat products, livestock demand is expected to double between 2000 and 2050 [3]. However, livestock farming is detrimental to the environment due to its contribution to greenhouse gas emissions and consumption of resources such as land and water [3,4]. As a result, alternative protein sources may be necessary to reduce the potential negative impacts of increased livestock production.

Alternative proteins are already available in the market such as plant-based proteins and cultured meat. Consumer acceptance of plant-based proteins has overall increased in the recent years as plant-based diets, health, and sustainability have been the main drivers for these products $[5,6]$. Cultured meat, or in vitro meat, has also been a growing industry due to its animal-friendly approach $[7,8]$. However, plant-based proteins have less food functionalities when compared to animal-based proteins, which may lead to concerns such as sensory appeal [9]. For cultured meat, the "unnatural" perception of lab-grown meat may be a deterrent for consumers [8]. Not to mention, those who may come from a lower socioeconomic background may not be as willing to purchase cultured meat due to its higher cost than conventional meat products [7]. Although there has been 
an increase in alternative proteins, one alternative may not necessarily meet the needs of certain consumer groups.

However, entomophagy, the practice of consuming insects, may be another alternative. Consuming insects has been a common practice for centuries, as it can be found in religious texts and continues to be a common food source among two billion people in Asia, Latin America, and Africa $[3,4,10,11]$. For regions lacking access to traditional protein sources, such as beef and pork, insects may be a promising alternative protein due to their nutritional profile, which can provide all essential amino acids necessary for humans [12-14]. Insects can provide a sustainable alternative for protein production, as they require less resources and produce lower greenhouse gas emissions than their traditional livestock counterparts $[1,4,11,15,16]$. Although insects may have their benefits, consumers may not easily accept them as a food source due to certain factors such as disgust.

Disgust, a culturally induced form of rejection, may deter Western consumers from adopting insects due to their association with filthiness and contamination [17-19]. Disgust was found to play a role in the intention to consume insects [20-22]. The Entomophagy Attitude Questionnaire (EAQ) developed by La Barbera et al. [20] found that disgust had a significant negative effect on the intention to consume insects in Western countries (Denmark and Italy). Verneau et al. [22] also used the EAQ in China, a non-Western country with a history of consuming insects, and they found that those who consumed insects self-reported less disgust and more intention to engage in entomophagy than those who did not eat insects. Woolf et al. [23] further suggests this, as a study conducted in the US found that those who have not consumed insect-based products considered their consumption disgusting. Western countries who do not have a previous history of consuming insects may experience disgust toward insects. As a result, disgust may act as a barrier for its future acceptance by consumers, especially in the Western market.

Therefore, identifying early adopters of insects may be necessary to promote insects as a food source. Early adopters, the initial group of consumers who gain interest in a certain product, play a role in the acceptance of novel foods and other innovations [24,25]. Once accepted by early adopters, widespread adoption of the new product may occur as early adopters promote and inadvertently communicate their adoption, leading to subsequent imitative behavior by other consumers $[25,26]$. Interest in consuming insects is related to consumers' curiosity to try new novel food experiences. It has been found that interest plays a positive role and may better predict the future acceptance of insects than disgust [20,22]. To increase interest in insects, more awareness of insects as a food source as well as its benefits may be necessary. Increased acceptance and willingness to eat insects has been found if consumers are aware of these benefits $[21,23,27,28]$. Consumer behavior plays a key role in the adoption of insects as food. Therefore, optimizing the insect-eating experiences through product delivery or form may be necessary when identifying early adopters [29]. For example, consumers may be more willing to accept processed insect-based foods such as a meal or powder incorporated into an appropriate food product [30]. Tan, Fischer, van Trijp, and Stieger [31] suggest that consumer preferences should be considered, as the perceived appropriateness of insect preparation may encourage its consumption.

To determine consumer preferences for an insect-based food product, one method may be through Preference Analysis. Preference Analysis, formerly known as Mind Genomics, is a recent and emerging scientific discipline that uses conjoint analysis to determine patterns in consumer responses toward selected information [32,33]. Preference analysis utilizes pre-selected elements regarding a certain product or service to form vignettes or concept ideas that are evaluated by respondents [32-34]. Then, respondents are clustered and segmented into groups or Mind-Sets that correspond to which elements they were most interested in during evaluation. Conjoint analysis is a relatively quick method in market/survey research to identify product features that may drive consumers to purchase a certain product. Intensive research has been conducted on the determinants that may prevent the consumption of insects, which may not necessarily identify what consumers may be looking for in an insect-based product. Previous research has been conducted using 
conjoint analysis to determine product features for insect-based products [33]. However, the development of newer software may help give better insight into products that may be deemed appropriate for consumers. This study was conducted to (1) identify early adopter Mind-Sets of insect-based food products, (2) determine product features early adopters would prefer in an insect-based food product, and (3) determine differences in Mind-Sets in different countries.

\section{Materials and Methods}

A questionnaire was developed and distributed into the US and the Philippines. Figure 1 shows how the questionnaire was developed into two studies for each country used and how participants were asked to respond.

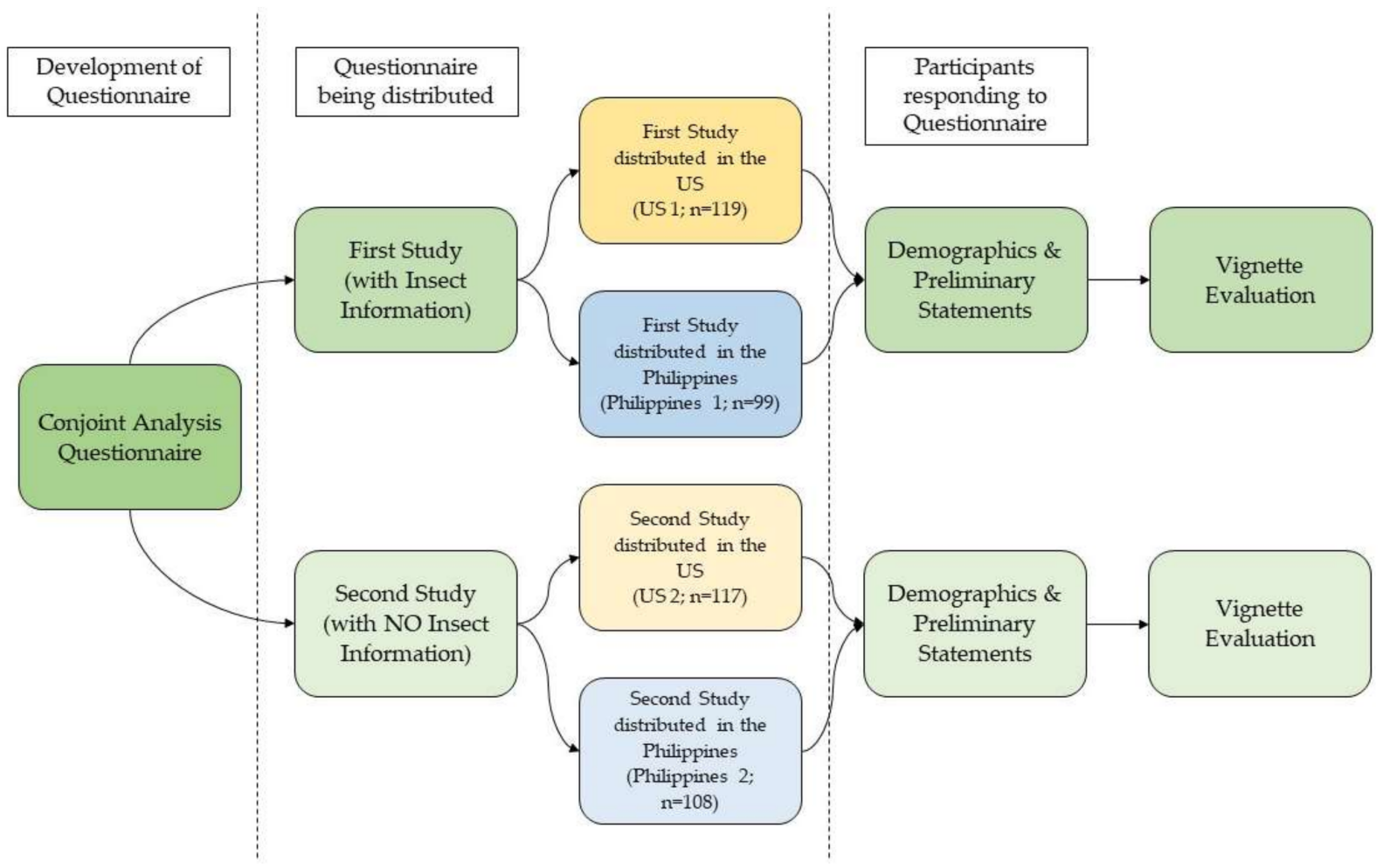

Figure 1. Flow diagram of the study approach.

\subsection{Data Collection and Questionnaire Design}

A conjoint analysis-based questionnaire was developed using BimiLeap ${ }^{\circledR}$, the DIY software developed by MindCart AI Inc. (Allentown, PA, USA) for Preference Analysis [32-34]. BimiLeap $^{\circledR}$ is a freely available browser-based software that allows users to create, run, and analyze studies utilizing Preference Analysis [34]. BimiLeap ${ }^{\circledR}$ was also selected because they had a database of subjects residing in both the US and the Philippines. Preference Analysis is a modified version of conjoint analysis, which uses four categories with each category having four elements each (16 elements in total).

Sixteen elements used in the study are presented by Table 1. Each element represents a product feature regarding an insect-based product (Product Form, Insect Type and Form, Interest, and Product Traits). Product Form was the main consideration to determine what consumers would prefer as the most appropriate food product contains insects. For Insect Type and Form, crickets and mealworms were selected, as they may be viable for food production as they are currently being farmed for human consumption [16,34]. The European Union had recently authorized yellow mealworms (Tenebrio molitor) safe for consumption as a "novel food" [35]. Insect powders and pure insect protein were selected, as previous research has found that consumers may be more accepting of insects in a nonvisible form and/or protein isolate by reducing the disgust factor of insects $[23,28,36-38]$. 
The Interest Category was based on the emotion terms ("active", "interested", "daring", and "secure") from the EsSense Profile [39]. These emotions were selected as consumers may either be interested in consuming insects either for their benefits or for their curiosity [40].

Table 1. Categories and their respective elements used in the study.

\begin{tabular}{cc}
\hline Code & Element \\
\hline A1 & Category A: Product Form \\
A2 & Snack food ... puffed snack, cracker, chip \\
A3 & Protein supplement ... bar, powder, shake \\
A4 & Carbohydrate ... bread, pasta \\
& Meat product ... burger patty, jerky, sausage \\
\hline B1 & Category B: Insect Type and Form \\
B2 & Ground whole cricket powder \\
B3 & Pure cricket protein \\
B4 & Ground whole mealworm powder \\
& Pure mealworm protein \\
\hline C1 & Category C: Interest (Emotion-Driven) \\
C2 & For an active lifestyle ... exercising, hiking, sports \\
C3 & New and daring food experience \\
C4 & For those interested in sustainable alternatives for the environment \\
& Providing friends and family with a secure food source \\
\hline D1 & Category D: Product Traits \\
D2 & Nutty flavor and aroma \\
D3 & High protein content similar to plant and meat products \\
D4 & Reduce greenhouse gas emissions and land/water usage \\
\hline
\end{tabular}

The questionnaire was distributed in the US and the Philippines. Two different countries were selected for this study to evaluate possible differences in Mind-Sets regarding insect-based products. The Philippines was selected as there is a history of insect consumption in the country with limited research conducted regarding insect-based foods [41]. The country was also selected, as English is spoken predominantly by the population to limit translation errors of the questionnaire [42]. Participants were found through BimiLeap's database, which allows for participant specification when recruiting. BimiLeap's software groups ages into seven age groups (13-17, 18-24, 25-34, 35-44, 45-54, 55-64, and 65+). For the study, participants were requested to be 18 and over with equal distributions across all age groups and genders (50\% male, $50 \%$ female).

Once the individuals from BimiLeap's database accepted the request to participate in the questionnaire, they received access through a website link. Once they entered BimiLeap's website through the link, participants then answered questions regarding demographics. During this section, participants were also asked to select a preliminary statement they most agree with (Table 2). The four preliminary statements were based on the Entomophagy Attitude Questionnaire (EAQ) [20]. Three of the four statements were selected from the Interest statements (EAQ-I) with the fourth statement based on the Disgust statements (EAQ-D) from the EAQ.

Then, participants were asked to evaluate the elements used in this study (Figure 2). BimiLeap ${ }^{\circledR}$ combines $2-4$ elements, one from each category, into a vignette, a concept idea about the given topic [34]. Participants evaluated each vignette using a 9-point Likert scale. Each participant evaluated 24 vignettes with combinations varying between participants. All vignettes contained only one element from each category, but not all categories are used [34]. All elements used had equal presentation during evaluation. 
Table 2. Preliminary statements participants had to select during the demographics portion of the questionnaire. Statements were based on La Barbera et al. [20].

\begin{tabular}{cc}
\hline Description & Preliminary Statement \\
\hline \multirow{3}{*}{ Interest (EAQ-I) } & I'd be curious to taste a dish with insects, if cooked well. \\
\cline { 2 - 2 } & In special circumstances, I might try to eat a dish of insects. \\
\cline { 2 - 2 } Disgust (EAQ-D) & I would avoid eating a dish with insects among the ingredients, even if it \\
was cooked by a famous chef.
\end{tabular}

The purpose of this study is to identify different mindsets around food products and the product features that they may prefer.

\section{Consider the ENTIRE VIGNETTE as ONE IDEA}

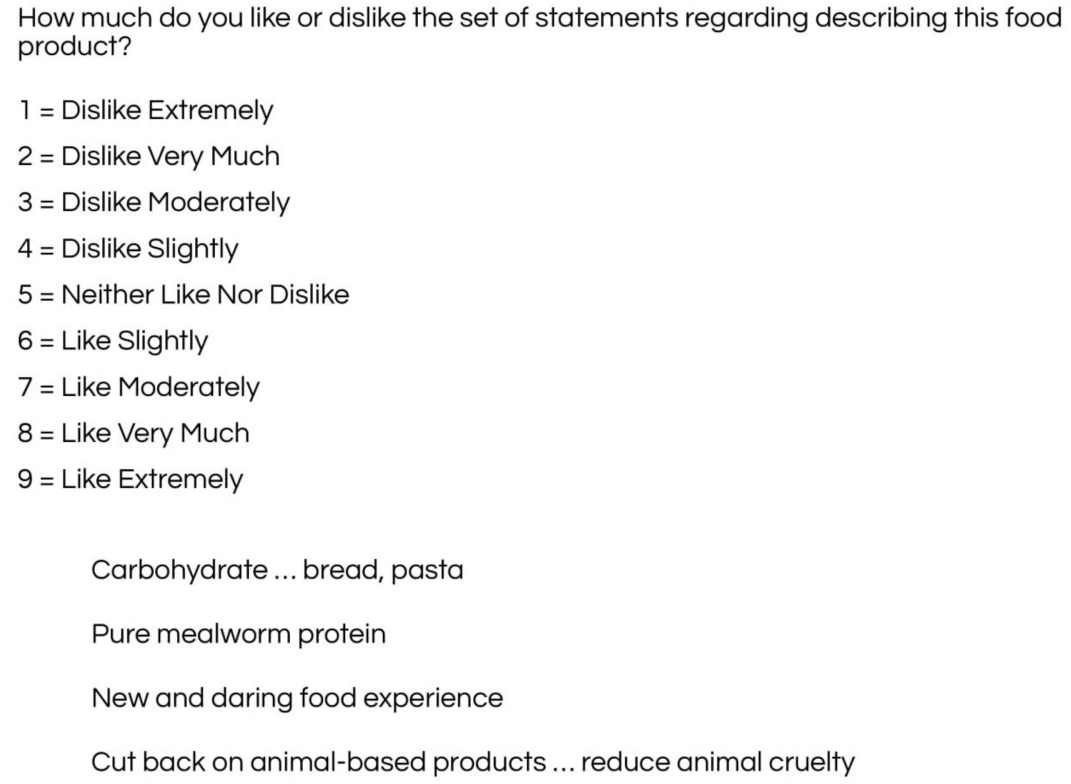

Figure 2. An example of a vignette a participant could see during the questionnaire.

\subsection{Role of Information}

When using the BimiLeap ${ }^{\circledR}$ program, users prewrite the questions and preliminary statements into the software that the participants will read when going through the questionnaire. For example, the participants were asked, "How much do you like or dislike the set of statements regarding an insect-based food product?" when evaluating the vignettes. When evaluating insects as a food source, participants may have a preconceived perception toward them, which may inadvertently affect how they may respond to the vignettes. Therefore, two questionnaires were distributed online in the US and the Philippines. The first questionnaire had insect information embedded into statements used when participants are reading the questionnaire. The second questionnaire was modified, so that participants were unaware that the questionnaire was about evaluating insect-based products. Table 3 shows how the preliminary statements participants would select were modified for the purposes of the second questionnaire. Participants were requested to be different during recruitment between studies conducted in each country. 
Table 3. Example of modification of the study to limit information regarding insects that was embedded into the questionnaire. The phrases underlined were an example of how the study was modified between each study.

\begin{tabular}{cc}
\hline First Study (Insect Information) & Second Study (No Insect Information) \\
\hline $\begin{array}{c}\text { I'd be curious to taste a dish with } \\
\text { insects, if cooked well. }\end{array}$ & $\begin{array}{c}\text { I'd be curious to taste a new } \\
\text { dish, if cooked well. }\end{array}$ \\
\hline $\begin{array}{c}\text { In special circumstances, I might } \\
\text { try to eat a dish of insects. }\end{array}$ & $\begin{array}{c}\text { In special circumstances, } \\
\text { I might try to eat a new dish. }\end{array}$ \\
\hline $\begin{array}{c}\text { At a dinner with friends, I would } \\
\text { try new foods prepared with insect flour. }\end{array}$ & $\begin{array}{c}\text { At a dinner with friends, } \\
\text { I would try new foods. }\end{array}$ \\
\hline $\begin{array}{c}\text { I would avoid eating a dish with insects among the } \\
\text { ingredients, even if it was cooked by a famous chef. }\end{array}$ & $\begin{array}{c}\text { I would avoid eating a new dish, even if } \\
\text { it was cooked by a famous chef. }\end{array}$ \\
\hline
\end{tabular}

\subsection{Data Analysis}

\subsubsection{BimiLeap ${ }^{\circledR}$ Program}

The program BimiLeap ${ }^{\circledR}$ runs ordinary least squares regression (OLS). The program first transforms the rating scale into a binary scale to evaluate weak and strong liking toward the elements used in the questionnaire. When using a 9-point scale, ratings of 1-6 from the scale are transformed to 0 (weak liking), and ratings of 7-9 on the scale are transformed to 100 (strong liking). Although the information collected is metric (Likert scale), the transformation focuses on the conventions of consumer market research of a yes/no [34]. A small number between 0.01 and 0.1 is added after the transformation to each binary rating to add some variation to the ratings and make the data immune to "crashing" during the OLS regression in the case that participants were to rate all vignettes 1-6, or $7-9$, respectively.

The binary table of the present/absent values (codes as 0 for absent, 1 for present) represented the set of independent values, while the transformed rating scale is used as a dependent variable. OLS is ran individually on the 24 vignettes each participant evaluated. The regression models were estimated without the presence of an additive constant in the model [34]. The OLS generates a single equation of the form:

$$
\text { Binary Transformed Rating }=\mathrm{k}_{0}+\mathrm{k}_{1} \mathrm{~A} 1+\mathrm{k}_{2} \mathrm{~A} 2 \ldots \mathrm{k}_{16} \mathrm{D} 4
$$

where $\mathrm{k}_{0}$ is the base constant (or intercept) and $\mathrm{k}_{1}$ to $\mathrm{k}_{16}$ are the regression coefficients of the elements (A1-D4) used in the study [43]. Then, the regression analysis was run on an individual level, meaning that one vector of coefficients was defined for each participant. The respondents were clustered using $k$-means clustering based on the similarities and differences between their individual vectors of coefficients. The measure of distance between pairs of participants was defined as the quantity (1-R), where $\mathrm{R}$ is the Pearson correlation using the 16 regression coefficients of each participant. BimiLeap ${ }^{\circledR}$ clusters the participants into two groups, then into three groups, where these groups are referred to as "Mind-Sets". Each Mind-Set represents different patterns of thinking based on the topic of the study [44]. This study focused on the Mind-Sets identified after clustering into two groups, as the sample size for each study conducted in each country was relatively small (about $n=100$ ).

The results were re-analyzed using OLS regression with IBM SPSS statistics software Version 27 (SPSS ${ }^{\circledR}$ Inc., Chicago, IL, USA) to determine any significance. IBM SPSS statistics software was selected for OLS regression analysis due to the researchers' preference for analysis. The data defined each participant by their self-selected age, gender, and preliminary statements and were assigned to one of two Mind-Sets (clusters). OLS regression was conducted for all participants (Total), Preliminary Statements, gender (all males and females), and the participants who corresponded into each Mind-Set (Cluster 1 or 2). Each of the four studies were analyzed to compare differences between countries. The role 
of information regarding insects in the questionnaire was also compared between the four studies.

\subsubsection{Response Times}

Response times for each vignette were collected and analyzed using JMP Pro 15 statistics software (Cary, NC, USA) to determine if the information regarding insects embedded into the questionnaire affected how participants would respond. JMP Pro 15 statistics software was selected for response time analysis due to the researchers' preference for analysis. A Wilcoxon test was conducted on the response times as normal distribution could not be determined using the Shapiro-Wilk test $(p>0.05)$. Response times between the two questionnaires distributed in each country were evaluated.

\subsection{Ethics Statements}

This research was reviewed and approved by the Cal Poly San Luis Obispo Institutional Review Board (2020-222-OL).

\section{Results and Discussion}

Results were analyzed and discussed based on Demographics, Gender, Mind-Sets, Preliminary Statements, and Response Times. Demographics were based on the proportions of the gender groups from each study as well as proportions from Preliminary Statement selection. Gender was analyzed to determine possible differences between the gender groups from each study. Mind-Sets that were identified from the BimiLeap ${ }^{\circledR}$ software were shown to determine possible early adopters and their preferences. Preliminary Statements were also used to demonstrate if the selection of these statements gave more insight into product feature preference. Response times were discussed to further support the findings from this study.

\subsection{Demographics}

The demographic results can be found in Table 4 . There was a higher proportion of male participants for the studies conducted in the US than the studies performed in the Philippines. US participants had a higher proportion of participants from the $45-54$ and $65+$ age groups than participants collected from the Philippines.

The proportion of preliminary statements selected by participants was similar between the studies with insect information for both countries (Table 5). The proportion of US participants who selected the Interest statements (EAQ-I) and Disgust statement (EAQ-D) was about equal to the proportion of Filipino participants when compared (Table 2).

\subsection{Gender}

Table 6 shows the regression coefficients for all participants (Total) across all questions distributed in the US and the Philippines. The Additive Constant represents the base interest/liking of the topic, insect-based products. Based on the regression coefficients, the elements can be used to develop an optimum concept idea regarding the topic by determining which elements would increase the base interest/liking. Overall, participants from the questionnaire with insect information (US 1 and Philippines 1) neither liked nor disliked the elements used in the study, as the regression coefficients ranged from -3 to 2 with lower base liking (Additive Constant) when compared to the questionnaires without insect information (US 2 and Philippines 2). 
Table 4. Demographics summary of the four studies conducted. US 1 and Philippines 1 were the studies with insect information embedded into the questionnaire, while US 2 and Philippines 2 did NOT have insect information. All values were rounded to nearest tenth and shown in percentages (\%). Columns were color-coded to differentiate between the studies between each country and the versions with insect information and NO insect information.

\begin{tabular}{ccccc}
\hline & US 1 & US 2 & Philippines 1 & Philippines 2 \\
\hline GENDER & & & & \\
\hline Male & 54.6 & 52.1 & 44.4 & 48.1 \\
\hline Female & 45.4 & 47.9 & 56.6 & 51.9 \\
\hline AGE GROUP & & & & \\
\hline $18-24$ & 16.0 & 17.9 & 25.3 & 26.9 \\
\hline $25-34$ & 22.7 & 18.8 & 25.3 & 24.2 \\
\hline $35-44$ & 23.5 & 21.4 & 22.2 & 16.7 \\
\hline $45-54$ & 20.2 & 19.7 & 22.2 & 9.3 \\
\hline $55-64$ & 10.1 & 16.2 & 5.1 & 0.9 \\
\hline $65+$ & 7.6 & 6.0 & 0 & \\
\hline
\end{tabular}

Table 5. Proportions for the Preliminary Statement selection of the four studies conducted. US 1 and Philippines 1 were the studies with insect information embedded into the questionnaire while US 2 and Philippines 2 did NOT have insect information. All values were rounded to nearest tenth and shown in percentages (\%). Columns were color-coded to differentiate between the studies between each country and the versions with insect information and NO insect information.

\begin{tabular}{ccccc}
\hline Preliminary Statement & US 1 & US 2 & Philippines 1 & Philippines 2 \\
\hline $\begin{array}{c}\text { I'd be curious to taste a dish with insects, } \\
\text { if cooked well (EAQ-I). }\end{array}$ & 26.9 & - & 32.3 & - \\
\hline $\begin{array}{c}\text { In special circumstances, I might } \\
\text { try to eat a dish of insects (EAQ-I). }\end{array}$ & 18.5 & - & 14.1 & - \\
\hline $\begin{array}{c}\text { At a dinner with friends, I would try new foods } \\
\text { prepared with insect flour (EAQ-I). }\end{array}$ & 10.1 & - & 10.1 & - \\
\hline $\begin{array}{c}\text { I would avoid eating a new dish, even if } \\
\text { it was cooked by a famous chef (EAQ-D). }\end{array}$ & 44.5 & - & 43.4 & 58.3 \\
\hline I'd be curious to taste a new dish, if cooked well. & - & 64.1 & - & 17.6 \\
\hline $\begin{array}{c}\text { In special circumstances, } \\
\text { I might try to eat a new dish. }\end{array}$ & - & 20.5 & - & 20.4 \\
\hline At a dinner with friends, I would try new foods. & - & 9.4 & - & 3.7 \\
\hline $\begin{array}{c}\text { I would avoid eating a new dish, } \\
\text { even if it was cooked by a famous chef. }\end{array}$ & - & 6.0 & - & \\
\hline
\end{tabular}

When comparing the base liking across all studies (Total), the studies without insect information (US 2 and Philippines 2) had a higher base liking than the studies with insect information (US 1 and Philippines 1). The studies conducted in the Philippines comparatively had higher base liking than the studies conducted in the US. This may be supported, as countries with a history of consuming insects, such as in Asian countries, may be more familiar with insects as food than Western countries [45].

Male participants from US 1 liked the set of statements containing elements regarding Product Traits more than the female participants. However, female participants like elements from the Product Form category more than their male counterparts. In the second study US study (US 2), female participants rated their liking higher for elements under the Interest category than male participants. In the first Philippines study (Philippines 1), male participants rated the vignettes higher than female participants for elements regarding Product Form. However, male participants from the second Philippines study had rated higher liking for elements under the Insect Form and Interest categories than their female counterparts. Overall, male participants across all studies rated the vignettes higher than female participants when evaluating liking. Previous research suggests that males may 
be more willing to accept insects as a food source $[21,23,38]$. This may be a result of men, especially young males, being more willing to try novel foods than women [46]. However, females are more willing to adopt plant-based proteins into their diet than males [5]. Providing insect-based products for the male demographic may be an important consideration when expanding the alternative protein market.

Table 6. Additive constants and regression coefficients across all four studies conducted for all participants (Total) and both gender groups for their respective country. Columns were color-coded to differentiate between the studies between each country and the versions with insect information and $\mathrm{NO}$ insect information.

\begin{tabular}{|c|c|c|c|c|c|c|c|c|c|c|c|c|c|}
\hline & \multirow{2}{*}{$\begin{array}{c}\text { Country } \\
\text { Group } \\
\end{array}$} & \multicolumn{3}{|c|}{ US 1} & \multicolumn{3}{|c|}{ US 2} & \multicolumn{3}{|c|}{ Philippines 1} & \multicolumn{3}{|c|}{ Philippines 2} \\
\hline & & Total & Male & Female & Total & Male & Female & Total & Male & Female & Total & Male & Female \\
\hline & Base Size & 119 & 65 & 54 & 117 & 61 & 56 & 99 & 44 & 55 & 108 & 52 & 56 \\
\hline Code & $\begin{array}{l}\text { Additive Constant } \\
\text { (Base Liking) }\end{array}$ & 27 & 33 & 19 & 40 & 43 & 37 & 36 & 40 & 33 & 52 & 49 & 54 \\
\hline $\mathrm{A} 1$ & $\begin{array}{l}\text { Snack food ... puffed } \\
\text { snack, cracker, chip }\end{array}$ & -1 & -2 & 1 & -1 & 0 & -1 & 0 & 4 & -2 & 0 & -1 & 1 \\
\hline $\mathrm{A} 2$ & $\begin{array}{l}\text { Protein supplement ... } \\
\text { bar, powder, shake }\end{array}$ & -2 & -4 & 1 & 1 & 0 & 2 & 2 & 2 & 1 & 0 & 2 & -2 \\
\hline $\mathrm{A} 3$ & $\begin{array}{c}\text { Carbohydrate ... } \\
\text { bread, pasta }\end{array}$ & 0 & -3 & 3 & 0 & 1 & -1 & -1 & 4 & -5 & 1 & 4 & -1 \\
\hline $\mathrm{A} 4$ & $\begin{array}{c}\text { Meat product ... burger } \\
\text { patty, jerky, sausage }\end{array}$ & 1 & -1 & 3 & -2 & -4 & 0 & 1 & 4 & -2 & -1 & 0 & -3 \\
\hline B1 & $\begin{array}{l}\text { Ground whole } \\
\text { cricket powder }\end{array}$ & -1 & -1 & 0 & -1 & 1 & -3 & 0 & 0 & 0 & 1 & 4 & -3 \\
\hline B2 & Pure cricket protein & 0 & 0 & 1 & -3 & -5 & -1 & -1 & -2 & 1 & 0 & 3 & -2 \\
\hline B3 & $\begin{array}{l}\text { Ground whole } \\
\text { mealworm powder }\end{array}$ & -1 & -1 & 0 & -1 & 1 & -2 & -1 & -4 & 1 & 1 & 1 & 1 \\
\hline B4 & Pure mealworm protein & 0 & 1 & 0 & -1 & 0 & -3 & 2 & -2 & 4 & -1 & 4 & -5 \\
\hline $\mathrm{C} 1$ & $\begin{array}{l}\text { For an active lifestyle ... } \\
\text { exercising, hiking, sports }\end{array}$ & -3 & -4 & -1 & 1 & 0 & 1 & 2 & 3 & 0 & 6 & 8 & 5 \\
\hline $\mathrm{C} 2$ & $\begin{array}{l}\text { For those interested in } \\
\text { sustainable alternatives } \\
\text { for the environment }\end{array}$ & -1 & -2 & 0 & 0 & -2 & 2 & 2 & 4 & 1 & 3 & 7 & 0 \\
\hline $\mathrm{C} 3$ & $\begin{array}{l}\text { New and daring } \\
\text { food experience }\end{array}$ & 0 & -3 & 3 & 4 & 4 & 4 & -1 & -1 & -1 & 1 & 4 & 0 \\
\hline $\mathrm{C} 4$ & $\begin{array}{l}\text { Providing friends and } \\
\text { family with a } \\
\text { secure food source }\end{array}$ & -3 & -3 & -1 & 1 & -1 & 3 & -2 & -4 & -1 & 5 & 8 & 2 \\
\hline D1 & Nutty flavor and aroma & 3 & 4 & 2 & -3 & -4 & -2 & -1 & -3 & 1 & 3 & 4 & 2 \\
\hline D2 & $\begin{array}{l}\text { High protein content } \\
\text { similar to plant } \\
\text { and meat products }\end{array}$ & 2 & 4 & -1 & -3 & -3 & -2 & -2 & 0 & -3 & 1 & 1 & 1 \\
\hline D3 & $\begin{array}{l}\text { Reduce greenhouse gas } \\
\text { emissions and } \\
\text { land/water usage }\end{array}$ & 1 & 2 & 0 & -5 & -7 & -4 & 1 & -1 & 3 & -1 & 2 & -3 \\
\hline $\mathrm{D} 4$ & $\begin{array}{l}\text { Cut back on animal-based } \\
\text { products ... reduce } \\
\text { animal cruelty }\end{array}$ & 2 & 2 & 2 & -2 & -2 & -2 & 2 & 0 & 3 & 0 & 2 & -1 \\
\hline
\end{tabular}

\subsection{Mind-Sets}

The Mind-Sets of each study conducted, and their regression coefficients can be found in Table 7. When comparing the base liking across the four studies, the studies without insect information (US 2 and Philippines 2) had higher base liking than the studies with insect information (US 1 and Philippines 1). This indicates that the participants rated the elements in the studies without insect information higher than the studies with insect information. 
Table 7. Additive constant and regression coefficients for the Mind-Sets determined for the four studies where US 1 and Philippines 1 are the studies with insect information while US 2 and Philippines 2 are the studies with NO insect information. Values bolded and highlighted green were determined to be significant $(p<0.05)$. Columns were color-coded to differentiate between the studies between each country and the versions with insect information and NO insect information.

\begin{tabular}{|c|c|c|c|c|c|c|c|c|c|}
\hline & \multirow{2}{*}{$\begin{array}{c}\text { Country } \\
\text { Group }\end{array}$} & \multicolumn{2}{|c|}{ US 1} & \multicolumn{2}{|c|}{ US 2} & \multicolumn{2}{|c|}{ Philippines 1} & \multicolumn{2}{|c|}{ Philippines 2} \\
\hline & & MS 1 & MS 2 & MS 1 & MS 2 & MS 1 & MS 2 & MS 1 & MS 2 \\
\hline & Base Size & 66 & 53 & 47 & 70 & 43 & 56 & 46 & 62 \\
\hline Code & $\begin{array}{l}\text { Additive Constant } \\
\text { (Base Liking) }\end{array}$ & 31 & 23 & 50 & 33 & 37 & 36 & 60 & 48 \\
\hline A1 & $\begin{array}{l}\text { Snack food ... puffed snack, } \\
\text { cracker, chip }\end{array}$ & -5 & 4 & -1 & -1 & -9 & 8 & 7 & -5 \\
\hline A2 & $\begin{array}{l}\text { Protein supplement ... bar, } \\
\text { powder, shake }\end{array}$ & -9 & 7 & 2 & 1 & -4 & 5 & 7 & -5 \\
\hline A3 & Carbohydrate ... bread, pasta & -6 & 6 & -2 & 1 & -11 & 7 & 9 & -4 \\
\hline A4 & $\begin{array}{l}\text { Meat product ... burger patty, } \\
\text { jerky, sausage }\end{array}$ & -4 & 7 & -3 & -1 & -9 & 8 & 8 & -8 \\
\hline B1 & Ground whole cricket powder & 3 & -6 & -5 & 2 & 5 & -4 & -1 & 0 \\
\hline B2 & Pure cricket protein & 3 & -4 & -11 & 2 & 1 & -2 & 3 & -3 \\
\hline B3 & $\begin{array}{l}\text { Ground whole } \\
\text { mealworm powder }\end{array}$ & 2 & -5 & -3 & 0 & 6 & -6 & 0 & 1 \\
\hline B4 & Pure mealworm protein & 2 & -3 & -7 & 3 & 5 & -1 & -1 & -2 \\
\hline $\mathrm{C} 1$ & $\begin{array}{l}\text { For an active lifestyle ... } \\
\text { exercising, hiking, sports }\end{array}$ & -6 & 1 & -7 & 6 & 1 & 2 & 6 & 6 \\
\hline $\mathrm{C} 2$ & $\begin{array}{l}\text { For those interested in } \\
\text { sustainable alternatives for } \\
\text { the environment }\end{array}$ & 0 & -2 & -7 & 5 & 3 & 2 & 7 & 1 \\
\hline $\mathrm{C} 3$ & $\begin{array}{l}\text { New and daring } \\
\text { food experience }\end{array}$ & -2 & 3 & -7 & 12 & -2 & 0 & 3 & -1 \\
\hline $\mathrm{C} 4$ & $\begin{array}{l}\text { Providing friends and family } \\
\text { with a secure food source }\end{array}$ & -4 & 0 & -13 & 11 & -5 & 0 & 6 & 4 \\
\hline D1 & Nutty flavor and aroma & 6 & -1 & 6 & -9 & 0 & -1 & -5 & 8 \\
\hline D2 & $\begin{array}{l}\text { High protein content similar } \\
\text { to plant and meat products }\end{array}$ & 7 & -5 & -1 & -4 & 2 & -4 & -9 & 7 \\
\hline D3 & $\begin{array}{c}\text { Reduce greenhouse gas } \\
\text { emissions and } \\
\text { land/water usage }\end{array}$ & 3 & -1 & -3 & -7 & 3 & -1 & -9 & 4 \\
\hline D4 & $\begin{array}{l}\text { Cut back on } \\
\text { animal-based products ... } \\
\text { reduce animal cruelty }\end{array}$ & 2 & 2 & 3 & -5 & 3 & 0 & -9 & 6 \\
\hline
\end{tabular}

\subsubsection{Product Form}

In the US 1 study, MS 2 had higher element liking regarding Product Form than MS 1 (Table 7). MS 1 would rate the vignettes more negatively than MS 2 if Product Form elements were included in the vignette. However, the MS from the US 2 study (with NO insect information) neither liked nor disliked the vignettes when Product Form was included. MS 2 from US 1 may be more acceptable of an insect-based product if it were in the form of a protein supplement and/or meat product than MS 1, as it was found that the "protein supplement" element would negatively $(p<0.05)$ affect liking.

MS 1 from Philippines 1 may not accept an insect-based product if it were in the form of a carbohydrate (bread or pasta), as it negatively affected $(p<0.05)$ how MS 1 evaluated the vignettes. MS 1 from Philippines 2 relatively liked elements under this category, but no significance was found to determine what may be an optimum product form.

Perceived food appropriateness should be considered [31,47]. The low/neutral liking of the Product Form elements suggests that consumers may not deem these products appropriate with the addition of insects. However, other countries that may have more insect-based products available in their market may be more familiar with insects as food. 
Consumers may be more willing to try them, which could lead to higher liking if the study were conducted in other countries such as in Europe.

\subsubsection{Insect Form}

Regardless of the study, Insect Form was not rated highly. Thus, when comparing Mind-Sets across all studies, no significance $(p>0.05)$ could be found that suggests which insect (cricket or mealworm) or insect form (powder or protein isolate) would be acceptable by participants. Rather, the elements may have caused low or neutral rating of the vignettes, as it was found that "Pure cricket protein" was significantly negative $(p<0.05)$ for MS 1 of the US 2 study. Previous research has found that consumers may be more willing to consume insect foods in nonvisible forms than whole visible insects [37,38].

\subsubsection{Interest and Product Traits}

For the Interest category, MS 2 from the US 2 study found significant liking $(p<0.05)$ if "New and daring food experience" and "Providing ... a secure food source" were included in the vignettes. This suggests that products including these elements may be more acceptable by consumers. Positive emotions are an under-investigated factor regarding food-eating behavior [48]. Previous research has found that insect-based food products were positively correlated with emotions such as emotions of interest, understanding, daring, and adventurous [40]. Disgust, a negative emotion, has been studied as a predictor for the acceptance of insects as food. Adding messaging during testing regarding the benefits of consuming insects may increase the acceptance of novel insect-based products [49].

For Product Traits, the Mind-Sets determined from each study either liked or disliked the elements from this category. The elements used were either negative or positive, but still relatively low, and may not drive consumers to try products that include these elements. This can be further shown as MS 2 from the US 2 study where a "Nutty flavor and aroma" would significantly negatively affect $(p<0.05)$ liking of the vignettes. This may result from consumers' unfamiliarity with the sensory attributes of insects and insect-based products. Consumer appeal may be enhanced with more taste education of edible insects [50,51]. A study conducted on Italian professional athletes found that the protein content and curiosity of the texture were the main drivers to taste a protein bar containing cricket flour [52].

Overall, participants may not have had any interest in any of these two categories' elements. Consumers may not be driven by the environmental and sustainable benefits of insects. A study conducted in Italy found that issues concerning sustainability did not play a role in the acceptance of insects [53]. Another study found that some participants who were more willing to try foods containing insects were not driven by sustainable or socially impactful food-purchasing considerations [28]. Introducing insect-based products into other countries may have the same difficulty, as information on the sustainable benefits may not drive consumers to adopt insects as food.

\subsection{Preliminary Statements}

The regression coefficients based on the Preliminary Statements participants selected during the studies with insect information (US 1 and Philippines 1) can be found in Table 8. Analysis using OLS regression was based on the Preliminary Statements. A higher proportion of participants selected the "I'd be curious to taste ... " statement from both studies when comparing the EAQ-I statements. This is also supported when comparing the proportions of Preliminary Statement selection (Table 5). Participants that selected the statements regarding interest in consuming insects (EAQ-I) had comparatively higher base liking than participants who selected the statement regarding disgust (EAQ-D). Participants who selected the EAQ-D statement had a low base liking. This further supports that disgust is a deterrent for consumers when introducing insects as a food source. Participants who selected the "In special circumstances ... " statement, the elements were found to negatively affect how participants rated the vignettes. This may be a result of the participants referring to the statement as if consuming insects was a last resort if there were no other food options. 
Table 8. Additive constant and regression coefficients based on the selection of the Preliminary Statements from the studies with insect information (US 1 and Philippines 1) embedded into the questionnaire. Values highlighted green were determined to be significant $(p<0.05)$. EAQ-I 1 is "I'd be curious to taste a dish with insects, if cooked well." EAQ-I 2 is "In special circumstances, I might try to eat a dish of insects." EAQ-I 3 is "At a dinner with friends, I would try new foods prepared with insect flour." EAQ-D is "I would avoid eating a dish with insects among the ingredients, even if it was cooked by a famous chef." Columns were color-coded to differentiate between each Preliminary Statement.

\begin{tabular}{|c|c|c|c|c|c|c|c|c|c|}
\hline \multirow{4}{*}{ Code } & Group & \multicolumn{2}{|c|}{ EAQ-I 1} & \multicolumn{2}{|c|}{ EAQ-I 2} & \multicolumn{2}{|c|}{ EAQ-I 3} & \multicolumn{2}{|c|}{ EAQ-D } \\
\hline & Country & US & Philippines & US & Philippines & US & Philippines & US & Philippines \\
\hline & Base Size & 32 & 32 & 22 & 14 & 12 & 10 & 53 & 43 \\
\hline & Additive Constant (Base Liking) & 46 & 47 & 37 & 58 & 27 & 59 & 12 & 18 \\
\hline A1 & $\begin{array}{l}\text { Snack food ... puffed snack, } \\
\text { cracker, chip }\end{array}$ & -3 & 3 & -7 & -6 & 5 & -12 & 1 & 2 \\
\hline A2 & $\begin{array}{c}\text { Protein supplement ... bar, powder, } \\
\text { shake }\end{array}$ & -2 & 1 & -8 & -7 & -1 & -7 & 0 & 6 \\
\hline A3 & Carbohydrate ... bread, pasta & -3 & 2 & -6 & -7 & 2 & 1 & 3 & -2 \\
\hline A4 & $\begin{array}{c}\text { Meat product ... burger patty, jerky, } \\
\text { sausage }\end{array}$ & -1 & 4 & -3 & -1 & 10 & -10 & 2 & 0 \\
\hline B1 & Ground whole cricket powder & 0 & -2 & -11 & 3 & 8 & -6 & 2 & 1 \\
\hline $\mathrm{B} 2$ & Pure cricket protein & 3 & -3 & -9 & -4 & 1 & -11 & 3 & 4 \\
\hline B3 & Ground whole mealworm powder & 1 & -2 & -10 & -7 & -1 & -5 & 2 & 2 \\
\hline $\mathrm{B} 4$ & Pure mealworm protein & 0 & 2 & -6 & 3 & 3 & -6 & 2 & 1 \\
\hline $\mathrm{C} 1$ & $\begin{array}{c}\text { For an active lifestyle ... exercising, } \\
\text { hiking, sports }\end{array}$ & -5 & 0 & 0 & -3 & -7 & -8 & -2 & 6 \\
\hline $\mathrm{C} 2$ & $\begin{array}{l}\text { For those interested in sustainable } \\
\text { alternatives for the environment }\end{array}$ & 2 & -2 & -7 & -1 & -10 & -5 & 1 & 8 \\
\hline $\mathrm{C} 3$ & New and daring food experience & 0 & -4 & 1 & -4 & -7 & -20 & 0 & 7 \\
\hline $\mathrm{C} 4$ & $\begin{array}{l}\text { Providing friends and family with a } \\
\text { secure food source }\end{array}$ & -4 & -2 & -7 & -11 & 1 & -8 & 0 & 1 \\
\hline D1 & Nutty flavor and aroma & 8 & 0 & 2 & -11 & 7 & 4 & -1 & 1 \\
\hline D2 & $\begin{array}{l}\text { High protein content similar to } \\
\text { plant and meat products }\end{array}$ & 6 & 0 & 0 & -11 & 7 & 0 & -1 & 0 \\
\hline D3 & $\begin{array}{l}\text { Reduce greenhouse gas emissions } \\
\text { and land/water usage }\end{array}$ & -2 & 5 & 4 & -4 & 6 & 3 & -1 & 2 \\
\hline D4 & $\begin{array}{c}\text { Cut back on animal-based products } \\
\text {... reduce animal cruelty }\end{array}$ & 5 & 6 & 1 & -7 & 9 & 7 & -2 & 0 \\
\hline
\end{tabular}

In the US, participants who selected the interest statement regarding, "I'd be curious to eat a dish with insects ... " did not respond well to the elements based on relatively low regression coefficients. However, "Nutty flavor and aroma" was found to be significant $(p<0.05)$. Consumers who may be interested in consuming insect-based products may be looking more for the sensory appeal. Participants who selected the "At a dinner with friends ..." "elements were liked more when comparing the regression coefficients to the other statements chosen, as the "Meat product", "Ground whole cricket powder", and "Cut back on animal-based products" elements were significant $(p<0.05)$. Insects can be used as a meat extender to increase the yield of animal meat products by replacing the amount of meat with insects [54]. Research has found that using insects as meat extenders in meat products can have similar results for consumer acceptability when compared to conventional fully meat and plant-based products $[55,56]$. Consumers who may be interested in the sustainable benefits of insects may be interested in insect-based products that exhibit these product features. However, the number of participants who selected this statement from the study was relatively low from the total US participants $(10.1 \%)$. 
In the Philippines, participants that selected the EAQ-I statements either liked or disliked elements across all categories. Even with relatively high base liking, most of the elements would negatively affect how they rate the vignettes, although there was no significance $(p>0.05)$. This is especially for the participants who selected either "In special circumstances ..." " and "At a dinner with friends ..." "statements from the EAQ-I, as most of the regression coefficients were found to be negative.

Overall, the use of the EAQ may be useful when predicting consumers intention to consume insects or adopting insects into their diets [22,57]. Although it was a modified version of the questionnaire, participants who selected the EAQ-I statements exhibited higher base liking than the Mind-Sets (Table 7) determined across all studies when compared. The use of the EAQ may provide insight when identifying consumers who may be interested in consuming insects.

\subsection{Response Times}

Response times may demonstrate the importance of experimental designs when using Preference Analysis. A significant difference $(p<0.05)$ was found between the responses times between the studies conducted in the US. However, no significance was determined between the studies conducted in the Philippines. With the US studies, participants may have responded differently based on the information that was embedded into the questionnaire design regarding insects. US participants in the study with insect information (US 1) knowing that the questionnaire was about insects may have already gained disinterest when rating the vignettes. This may occur with participants quickly rating the vignettes without taking the time to read and go over the vignettes. This can be further supported, as the base liking for all participants (Total) was comparatively lower for the US 1 and Philippines 1 studies than the US 2 and Philippines 2.

\section{Conclusions}

Overall, this study found limited results identifying early adopter Mind-Sets of insectbased products for both in the US and the Philippines. Participants neither liked nor disliked the elements used for the overall study. The low base liking from the US studies may further support that US consumers may still not accept insects as a food source. Even though the Philippines does have a history of insect consumption, participants had little interest in the elements used. This may result from developing countries adopting Western culture, which may cause consumers to view insect consumption as "primitive" behavior and associated with low socioeconomic status. However, this may also be a result of the study's experimental design.

Preference Analysis and its software, BimiLeap ${ }^{\circledR}$, provide a quick and user-friendly method to conduct conjoint analyses and determine Mind-Sets to identify proper messaging based on responses. Pre-selection of the categories and elements used is important regarding to the topic. The elements from this study were not highly liked and may be a result of them being related to insect-based products based on the response times in the US studies. This shows the importance of how researchers should design their studies when using BimiLeap ${ }^{\circledR}$ software or any conjoint analysis study.

The Mind-Sets identified may show that consumers may not necessarily look for these specific product features used in the study. Rather, they may be interested in other aspects regarding insect-based foods that were not identified. However, certain elements were significant based on the EAQ-I statements when examining the Preliminary Statements. Pre-existing interest in consuming insects may be another way to identify early adopters of insect-based products.

From a product development standpoint, this study can give initial insight when developing new insect-based products and identifying potential target consumers. Further testing using Preference Analysis could provide substantial information when determining optimum product features. These identified product features can be validated using in-person product testing. Results from the study could be applied to other countries, 
as in-depth testing in European countries has found certain products acceptable by consumers [58]. However, product formulation should be considered, as some countries may value certain sensory aspects such as such as flavors and textures more than others depending on the product.

Limitations to this study may be the sample size for each individual study. A higher sample size may be able to identify different emerging Mind-Sets regarding insect-based products. Although a novel research discipline, Preference Analysis may be useful for those who may want to identify target groups for their products and what product features they may prefer.This study focused on using this methodology to identify early adopter Mind-Sets of insect-based products. However, the results support previous findings on the deterrents of insect based on the experimental design.

Author Contributions: Conceptualization, I.H. and A.L.; methodology, I.H., A.G., C.C. and A.L.; software, C.C.; validation, I.H., A.G., C.C. and A.L.; formal analysis, I.H.; investigation, I.H. and A.L.; resources, I.H., A.G., C.C. and A.L.; data curation, I.H. and A.L.; writing-original draft preparation, I.H.; writing-review and editing, I.H., A.G., C.C. and A.L.; visualization, I.H.; supervision, A.L.; project administration, A.L.; funding acquisition, A.L. All authors have read and agreed to the published version of the manuscript.

Funding: This work was supported by the California State University Agricultural Research Institute (Award No. 21-03-105).

Institutional Review Board Statement: The study was conducted in accordance with the Declaration of Helsinki, and approved by the Institutional Review Board of Cal Poly San Luis Obispo (2020-222-OL).

Informed Consent Statement: Informed consent was obtained from all subjects involved in the study.

Data Availability Statement: The data presented in this study are available on request from the corresponding author. The data are not publicly available due to privacy and ethical restrictions.

Acknowledgments: We would like to thank Sophia Davidov and Nathan Battersby from MindCart AI, Inc. for assisting us with our project in regard to data collection and analysis. AG thanks the support of János Bolyai Research Scholarship of the Hungarian Academy of Sciences and National Research, Development and Innovation Office of Hungary (OTKA, contract No. FK137577).

Conflicts of Interest: The authors declare no conflict of interest.

\section{References}

1. van Huis, A.; Van Itterbeeck, J.; Klunder, H.; Mertens, E.; Muir, G.; Vantomme, P. Edible Insects—Future Prospects for Food and Feed Security; FAO: Rome, Italy, 2013.

2. United Nations. Food Production Must Double by 2050 to Meet Demand from World's Growing Population, Innovative Strategies Needed to Combat Hunger, Experts Tell Second Committee; United Nations: New York, NY, USA, 2009.

3. Baiano, A. Edible Insects: An Overview on Nutritional Characteristics, Safety, Farming, Production Technologies, Regulatory Framework, and Socio-Economic and Ethical Implications. Trends food Sci. Technol. 2020, 100, 35-50. [CrossRef]

4. Govorushko, S. Global Status of Insects as Food and Feed Source: A Review. In Trends in Food Science and Technology; Elsevier: London, UK, 2019; pp. 436-445. [CrossRef]

5. Onwezen, M.C.; Bouwman, E.P.; Reinders, M.J.; Dagevos, H. A Systematic Review on Consumer Acceptance of Alternative Proteins: Pulses, Algae, Insects, Plant-Based Meat Alternatives, and Cultured Meat. Appetite 2021, 159, 105058. [CrossRef] [PubMed]

6. Niva, M.; Vainio, A. Towards More Environmentally Sustainable Diets? Changes in the Consumption of Beef and Plant- and Insect-Based Protein Products in Consumer Groups in Finland. Meat Sci. 2021, 182, 108635. [CrossRef] [PubMed]

7. Tucker, C.A. The Significance of Sensory Appeal for Reduced Meat Consumption. Appetite 2014, 81, 168-179. [CrossRef]

8. Siegrist, M.; Sütterlin, B.; Hartmann, C. Perceived Naturalness and Evoked Disgust Influence Acceptance of Cultured Meat. Meat Sci. 2018, 139, 213-219. [CrossRef]

9. Sagis, L.M.; Yang, J. Protein-Stabilized Interfaces in Multiphase Food: Comparing Structure-Function Relations of Plant-Based and Animal-Based Proteins. Curr. Opin. Food Sci. 2022, 43, 53-60. [CrossRef]

10. van Huis, A. Insects as Human Food. In Ethnozoology Animals in Our Lives; Elsevier: London, UK, 2018; pp. 195-213. [CrossRef]

11. Rumpold, B.A.; Schlüter, O.K. Potential and Challenges of Insects as an Innovative Source for Food and Feed Production. Innov. Food Sci. Emerg. Technol. 2013, 17, 1-11. [CrossRef]

12. de Castro, R.J.; Ohara, A.; dos Santos Aguilar, J.G.; Domingues, M.A. Nutritional, Functional and Biological Properties of Insect Proteins: Processes for Obtaining, Consumption and Future Challenges. Trends Food Sci. Technol. 2018, 76, 82-89. [CrossRef] 
13. Jantzen da Silva Lucas, A.; Menegon de Oliveira, L.; da Rocha, M.; Prentice, C. Edible Insects: An Alternative of Nutritional, Functional and Bioactive Compounds. Food Chem. 2020, 311, 126022. [CrossRef]

14. Sun-Waterhouse, D.; Waterhouse, G.I.N.; You, L.; Zhang, J.; Liu, Y.; Ma, L.; Gao, J.; Dong, Y. Transforming Insect Biomass into Consumer Wellness Foods: A Review. Food Res. Int. 2016, 89, 129-151. [CrossRef]

15. Dossey, A.T.; Tatum, J.T.; McGill, W.L. Modern Insect-Based Food Industry: Current Status, Insect Processing Technology, and Recommendations Moving Forward. In Insects as Sustainable Food Ingredients; Elsevier: London, UK, 2016; pp. 113-152. [CrossRef]

16. Gahukar, R.T. Edible Insects Farming: Efficiency and Impact on Family Livelihood, Food Security, and Environment Compared With Livestock and Crops. In Insects as Sustainable Food Ingredients; Elsevier: London, UK, 2016; pp. 85-111. [CrossRef]

17. La Barbera, F.; Verneau, F.; Amato, M.; Grunert, K. Understanding Westerners' Disgust for the Eating of Insects: The Role of Food Neophobia and Implicit Associations. Food Qual. Prefer. 2018, 64, 120-125. [CrossRef]

18. Mancini, S.; Sogari, G.; Menozzi, D.; Nuvoloni, R.; Torracca, B.; Moruzzo, R.; Paci, G. Factors Predicting the Intention of Eating an Insect-Based Product. Foods 2019, 8, 270. [CrossRef]

19. Orsi, L.; Voege, L.L.; Stranieri, S. Eating Edible Insects as Sustainable Food? Exploring the Determinants of Consumer Acceptance in Germany. Food Res. Int. 2019, 125, 108573. [CrossRef] [PubMed]

20. La Barbera, F.; Verneau, F.; Videbæk, P.N.; Amato, M.; Grunert, K.G. A Self-Report Measure of Attitudes toward the Eating of Insects: Construction and Validation of the Entomophagy Attitude Questionnaire. Food Qual. Prefer. 2020, 79, 103757. [CrossRef]

21. Ruby, M.B.; Rozin, P. Disgust, Sushi Consumption, and Other Predictors of Acceptance of Insects as Food by Americans and Indians. Food Qual. Prefer. 2019, 74, 155-162. [CrossRef]

22. Verneau, F.; Zhou, Y.; Amato, M.; Grunert, K.G.; La Barbera, F. Cross-Validation of the Entomophagy Attitude Questionnaire (EAQ): A Study in China on Eaters and Non-Eaters. Food Qual. Prefer. 2021, 87, 104029. [CrossRef]

23. Woolf, E.; Zhu, Y.; Emory, K.; Zhao, J.; Liu, C. Willingness to Consume Insect-Containing Foods: A Survey in the United States. LWT 2019, 102, 100-105. [CrossRef]

24. House, J. Consumer Acceptance of Insect-Based Foods in the Netherlands: Academic and Commercial Implications. Appetite 2016, 107, 47-58. [CrossRef]

25. Frattini, F.; Bianchi, M.; De Massis, A.; Sikimic, U. The Role of Early Adopters in the Diffusion of New Products: Differences between Platform and Nonplatform Innovations. J. Prod. Innov. Manag. 2014, 31, 466-488. [CrossRef]

26. Rogers, E.M. Diffusion of Innovations; Free Press: New York, NY, USA, 2003.

27. Lombardi, A.; Vecchio, R.; Borrello, M.; Caracciolo, F.; Cembalo, L. Willingness to Pay for Insect-Based Food: The Role of Information and Carrier. Food Qual. Prefer. 2019, 72, 177-187. [CrossRef]

28. Rovai, D.; Michniuk, E.; Roseman, E.; Amin, S.; Lesniauskas, R.; Wilke, K.; Garza, J.; Lammert, A. Insects as a Sustainable Food Ingredient: Identifying and Classifying Early Adopters of Edible Insects Based on Eating Behavior, Familiarity, and Hesitation. J. Sens. Stud. 2021, 36, e12681. [CrossRef]

29. Ardoin, R.; Prinyawiwatkul, W. Consumer Perceptions of Insect Consumption: A Review of Western Research since 2015. Int. J. Food Sci. Technol. 2021, 56, 4942-4958. [CrossRef]

30. Hartmann, C.; Siegrist, M. Becoming an Insectivore: Results of an Experiment. Food Qual. Prefer. 2016, 51, 118-122. [CrossRef]

31. Tan, H.S.G.; Fischer, A.R.H.; van Trijp, H.C.M.; Stieger, M. Tasty but Nasty? Exploring the Role of Sensory-Liking and Food Appropriateness in the Willingness to Eat Unusual Novel Foods like Insects. Food Qual. Prefer. 2016, 48, 293-302. [CrossRef]

32. Moskowitz, H.R. 'Mind Genomics': The Experimental, Inductive Science of the Ordinary, and Its Application to Aspects of Food and Feeding. Physiol. Behav. 2012, 107, 606-613. [CrossRef] [PubMed]

33. Porretta, S.; Gere, A.; Radványi, D.; Moskowitz, H. Mind Genomics (Conjoint Analysis): The New Concept Research in the Analysis of Consumer Behaviour and Choice. Trends Food Sci. Technol. 2019, 84, 29-33. [CrossRef]

34. Gere, A.; Harizi, A.; Bellissimo, N.; Roberts, D.; Moskowitz, H. Creating a Mind Genomics Wiki for Non-Meat Analogs. Sustainability 2020, 12, 5352. [CrossRef]

35. EU. Approval of First Insect as Novel Food. Available online: https://ec.europa.eu/food/safety/novel-food/authorisations/ approval-first-insect-novel-food_en (accessed on 7 October 2021).

36. Castro Delgado, M.; Chambers, E.; Carbonell-Barrachina, A.; Noguera Artiaga, L.; Vidal Quintanar, R.; Burgos Hernandez, A. Consumer Acceptability in the USA, Mexico, and Spain of Chocolate Chip Cookies Made with Partial Insect Powder Replacement. J. Food Sci. 2020, 85, 1621-1628. [CrossRef]

37. Jensen, N.H.; Lieberoth, A. We Will Eat Disgusting Foods Together-Evidence of the Normative Basis of Western EntomophagyDisgust from an Insect Tasting. Food Qual. Prefer. 2019, 72, 109-115. [CrossRef]

38. Lammers, P.; Ullmann, L.M.; Fiebelkorn, F. Acceptance of Insects as Food in Germany: Is It about Sensation Seeking, Sustainability Consciousness, or Food Disgust? Food Qual. Prefer. 2019, 77, 78-88. [CrossRef]

39. King, S.C.; Meiselman, H.L. Development of a Method to Measure Consumer Emotions Associated with Foods. Food Qual. Prefer. 2010, 21, 168-177. [CrossRef]

40. Serpico, M.; Rovai, D.; Wilke, K.; Lesniauskas, R.; Garza, J.; Lammert, A. Studying the Emotional Response to Insects Food Products. Foods 2021, 10, 2404. [CrossRef]

41. Adalla, C.B.; Cervancia, C.R. Philippine Edible Insects: A New Opportunity to Bridge the Protein Gap of Resource-Poor Families and to Manage Pests. RAP Publ. 2010, 02, 151-160.

42. Bolton, K.; Bacon-Shone, J. The Statistics of English across Asia. Handb. Asian Englishes 2020, 1, 49-80. [CrossRef] 
43. Harizi, A.; Trebicka, B.; Tartaraj, A.; Howard, M. A Mind Genomics Cartography of Shopping Behavior for Food Products during the Covid-19 Pandemic. Eur. J. Med. Nat. Sci. Artic. 2020, 4, 25-33. [CrossRef]

44. Gere, A.; Zemel, R.; Papajorgij, P.; Radványi, D.; Moskowitz, H. Public Driven and Public Perceptible Innovation of Environmental Sector. In Innovation Strategies in Environmental Science; Elsevier: London, UK, 2020; pp. 69-106. [CrossRef]

45. Sogari, G.; Menozzi, D.; Hartmann, C.; Mora, C. How to Measure Consumers Acceptance towards Edible Insects?-A Scoping Review about Methodological Approaches. Edible Insects Food Sect. 2019, 27-44. [CrossRef]

46. Verbeke, W. Profiling Consumers Who Are Ready to Adopt Insects as a Meat Substitute in a Western Society. Food Qual. Prefer. 2015, 39, 147-155. [CrossRef]

47. Tan, H.S.G.; Verbaan, Y.T.; Stieger, M. How Will Better Products Improve the Sensory-Liking and Willingness to Buy Insect-Based Foods? Food Res. Int. 2017, 92, 95-105. [CrossRef] [PubMed]

48. Evers, C.; Adriaanse, M.; de Ridder, D.T.D.; de Witt Huberts, J.C. Good Mood Food. Positive Emotion as a Neglected Trigger for Food Intake. Appetite 2013, 68, 1-7. [CrossRef]

49. Onwezen, M.C.; van den Puttelaar, J.; Verain, M.C.D.; Veldkamp, T. Consumer Acceptance of Insects as Food and Feed: The Relevance of Affective Factors. Food Qual. Prefer. 2019, 77, 51-63. [CrossRef]

50. Mishyna, M.; Chen, J.; Benjamin, O. Sensory Attributes of Edible Insects and Insect-Based Foods—Future Outlooks for Enhancing Consumer Appeal. Trends Food Sci. Technol. 2020, 95, 141-148. [CrossRef]

51. Pambo, K.O.; Okello, J.J.; Mbeche, R.M.; Kinyuru, J.N.; Alemu, M.H. The Role of Product Information on Consumer Sensory Evaluation, Expectations, Experiences and Emotions of Cricket-Flour-Containing Buns. Food Res. Int. 2018, 106, 532-541. [CrossRef] [PubMed]

52. Placentino, U.; Sogari, G.; Viscecchia, R.; De Devitiis, B.; Monacis, L. The New Challenge of Sports Nutrition: Accepting Insect Food as Dietary Supplements in Professional Athletes. Foods 2021, 10, 1117. [CrossRef]

53. Laureati, M.; Bergamaschi, V.; Pagliarini, E. School-Based Intervention with Children. Peer-Modeling, Reward and Repeated Exposure Reduce Food Neophobia and Increase Liking of Fruits and Vegetables. Appetite 2014, 83, 26-32. [CrossRef]

54. Pintado, T.; Delgado-Pando, G. Towards More Sustainable Meat Products: Extenders as a Way of Reducing Meat Content. Foods 2020, 9, 1044. [CrossRef] [PubMed]

55. Caparros Megido, R.; Gierts, C.; Blecker, C.; Brostaux, Y.; Haubruge, É.; Alabi, T.; Francis, F. Consumer Acceptance of Insect-Based Alternative Meat Products in Western Countries. Food Qual. Prefer. 2016, 52, 237-243. [CrossRef]

56. Choi, Y.S.; Kim, T.K.; Choi, H.D.; Park, J.D.; Sung, J.M.; Jeon, K.H.; Paik, H.D.; Kim, Y.B. Optimization of Replacing Pork Meat with Yellow Worm (Tenebrio Molitor L.) for Frankfurters. Korean J. Food Sci. Anim. Resour. 2017, 37, 617. [CrossRef]

57. La Barbera, F.; Verneau, F.; Amato, M.; Grunert, K.G.; Schnettler, B. Acceptance of Insect-Based Food in Chile: Evidence from a Survey Using the Entomophagy Attitude Questionnaire (EAQ). Food Qual. Prefer. 2021, 93, 104269. [CrossRef]

58. Mancini, S.; Moruzzo, R.; Riccioli, F.; Paci, G. European Consumers' Readiness to Adopt Insects as Food. A Review. Food Res. Int. 2019, 122, 661-678. [CrossRef] 